Emir. J. Food Agric. 2009. 21 (1): 32-39

http://cfa.uaeu.ac.ae/ejfa.shtml

\title{
Rumen degradability and kinetic properties of urea and poultry litter treated rice straw
}

\author{
M. B. Ngele, T. A. Adegbola, S. E. S. Bogoro, M. Abubakar and D. J. U. Kalla \\ Animal Production Programme, School of Agriculture, Abubakar Tafawa Balewa \\ University, Bauchi, Bauchi State, Nigeria
}

\begin{abstract}
Rumen degradation and kinetic properties of rice straw subjected to urea and poultry litter treatments was investigated. The crude protein (CP) content of the straw was significantly $(\mathrm{P}<0.05)$ increased from $4.44 \%$ for the untreated rice straw (URS) to $12.35,20.46$ and $19.72 \%$ for urea-treated rice straw (UTRS), poultry litter treated rice straw (PLTRS1) and poultry litter treated rice straw (PLTRS2), respectively. The dry matter (DM) degradability of the treated straw was consistently higher than that of the untreated straw, whereas the rate constants (c) for the untreated and treated straw were similar. The study showed a close relationship between the comparative degradability rate (c) and outflow rate $(\mathrm{k})$ at $24 \mathrm{hr}$ incubation of the rice straw. The effective degradability of the straw was influenced by the rapidly soluble fraction (a) and the rate constant (c) for degradation of the straw. Urea-ammoniation thus, increased the CP of crop residues and its degradability in the rumen. Also, the use of poultry litter can be a suitable alternative to urea fertilizer in treating crop residues and reduces the problem of animal waste disposal. The trial also shows that equal proportion of rice straw to poultry litter is more effective in the treatment of straw.
\end{abstract}

Keywords: Kinetics, poultry litter, rice straw, rumen degradability, urea.

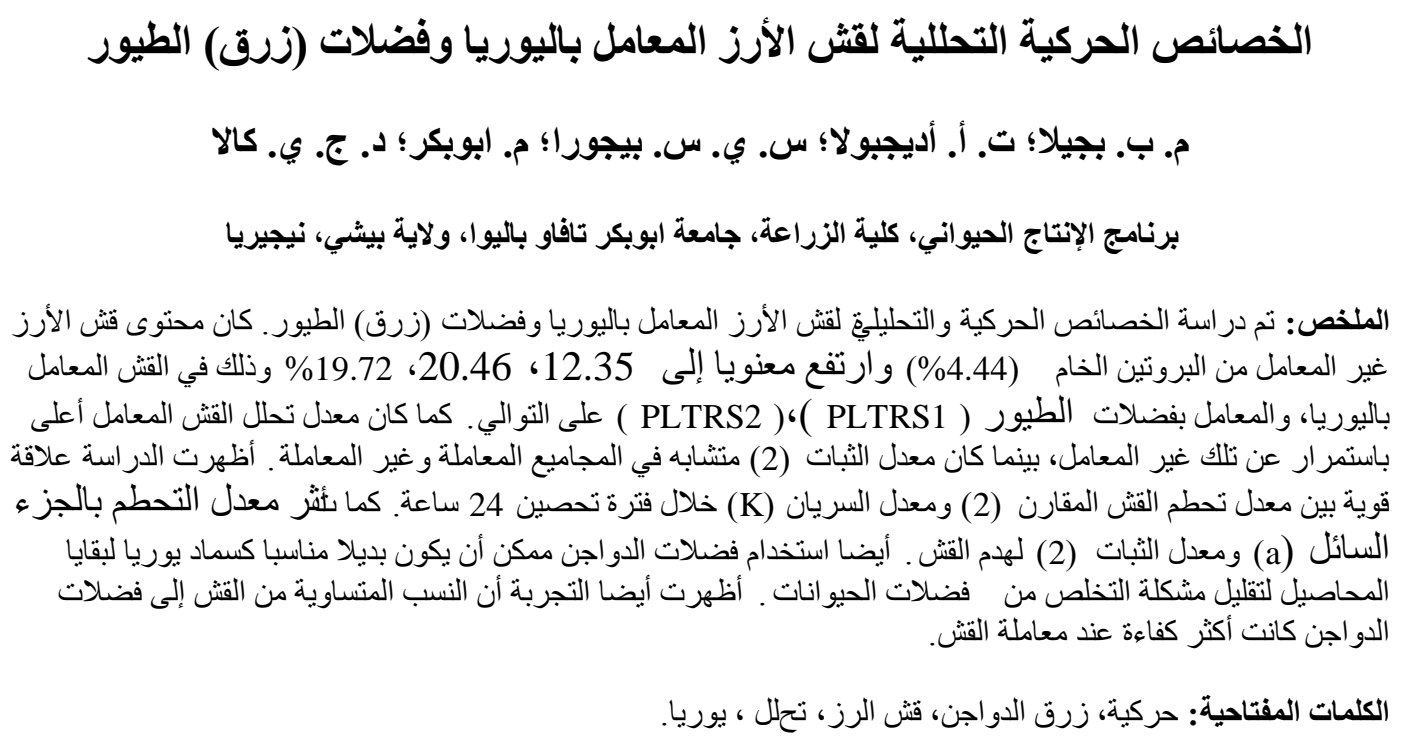

\section{Introduction}

Adequate nutrition, being an important factor in production is a major necessity that is difficult to meet while rearing livestock in Nigeria. Animal feeds are in short supply thereby leading to a wide gap between demand and supply of feed and fodder. The situation is worse during the long dry season which lasts for about seven months. During such periods, fibre-rich, low protein forages and crop residues are the most abundant feeds for ruminants. Consequently, animals are not able to meet their protein and energy needs, and the deficiency is noticed as 
drastic weight loss and decreased productivity (Adegbola et al., 1988; Nuru, 1993).

Cereal straw or stovers are the main crop residues available for ruminant feeding during the dry season in Northern Nigeria. These crop residues grazed on by pastoralists account for a large proportion of the animals' total grazing in the dry season (Bayer, 1986). In the absence of high quality forage in the dry season, these residues still, and will remain the main feed resource for smallholder livestock farmers in most developing countries. The crop residues are low in nitrogen, minerals, vitamins and available energy and are of low digestibility (Sundstol and Owen, 1984; Kibon, 1999). Over the years more attention has been paid to raising the nutritive value of crop residues. Alkali treatment of straw is generally considered to increase the rate and extent of digestion (Chesson and Orskov, 1984). In addition, there is limited information available to small scale farmers in developing countries like Nigeria, on the rumen degradation characteristics of crop residues subjected to various urea treatments. The utilization of roughage by ruminant animals is largely dependent upon microbial degradation within the rumen. Therefore, description of roughage in terms of their degradation characteristics would provide a useful guide for ranking on the basis of nutritive value and efficiency of treatment methods.

The use of the "nylon bag" technique in estimating both the rate and extent of disappearance of feedstuffs from the rumen has been described by Mehrez and Orskov, (1977), Kempton (1980), Orskov et al. (1980). The simplicity and cost effectiveness of the technique necessitates its wide usage for feed evaluation especially in developing countries, where there is rapid communication of information on feed quality without resorting to highly technical and expensive laboratory procedures.
The objective of this study was to assess the rumen degradability and kinetic properties of rice straw subjected to urea and poultry litter treatments.

\section{Materials and Methods}

\section{Collection and treatment of rice straw}

Rice straw (RS) was collected from experimental rice farms of Crop Production Programme, School of Agriculture, Abubakar Tafawa Balewa University, Bauchi. The trial was set up to evaluate the productivity of FARO 44/SIP1692033 in a swampy area. Straw samples collected from the trial plots were poled for the study. FARO 44/SIP1692033 is the most predominant rice variety grown in the Northern Guinea Savannah area. The RS, consisting of the leaf and straw portions, was gathered from the field immediately after harvesting, chopped manually using a matchet to a length of 3$5 \mathrm{~cm}$.

The RS was divided into three portions, and the first portion was not subjected to any treatment besides the chopping - this was referred to as untreated rice straw (URS) or control. The second portion of the chopped rice straw was treated using urea fertilizer at $4 \%$. This was done by dissolving $4 \mathrm{~kg}$ of urea in 100 litres of water to treat $100 \mathrm{~kg}$ RS. The RS was treated by sprinkling it with the $4 \%$ urea solution in a metal drum that was lined with a polythene sheet. The mixture was tightly closed (air tight) for a period of 21days. After the 21days, the ensiled RS was spread in open air under shade for three days to enable cooling and escape of ammonia gas. This treated RS was called urea-treated rice straw (UTRS). The third portion of the chopped RS was treated using poultry litter (broiler litter). The litter was milled through a $2 \mathrm{~mm}$ sieve to ensure thorough mixing of the litter components. The RS was mixed with poultry litter (PL) in two different ratios, 5:5 and 6:4. Equal amounts of water was mixed with each of the rice straw + 
poultry litter (RSPL) mixture in equal proportions (50:50) which happened to be the best combination as earlier reported (Ngele et al., 2003). The mixture was then put into polythene bags, tightly closed and kept in metal drums for a 21days as an ensilage period. After the 21days, the material was dried under shade for three days, and this mixture was referred to as poultry litter treated rice straw (PLTRS). The ratio of rice straw to poultry litter (RS: PL), 5:5 and 6:4 on dry matter basis was designated as PLTRS1 and PLTRS2, respectively. These two combinations were the best in terms of increased crude protein $(\mathrm{CP})$ and decreased crude fiber Table 1 (Ngele et al., 2003).

Table 1. Chemical composition of Unprocessed and processed poultry litter (\% DM).

\begin{tabular}{lccccc}
\hline Composition $^{\mathbf{1}}$ & UPL & SDPL & EPL & SE & LOS \\
\hline Dry matter & 90.4 & 89.1 & 92.2 & 1.44 & NS \\
Crude protein & $18.3^{\mathrm{b}}$ & $27.3^{\mathrm{a}}$ & $28.1^{\mathrm{a}}$ & 5.50 & $*$ \\
Organic Matter & $82.5^{\mathrm{a}}$ & $73.4^{\mathrm{b}}$ & $85.3^{\mathrm{a}}$ & 3.41 & $*$ \\
NDF & 50.3 & 50.7 & 48.4 & 2.30 & NS \\
ADF & 40.6 & 39.9 & 42.9 & 2.99 & NS \\
Hemicellulose & 9.7 & 10.8 & 5.5 & 5.29 & NS \\
Ether extract & $1.6^{\mathrm{ab}}$ & $1.7^{\mathrm{a}}$ & $0.7^{\mathrm{b}}$ & 0.87 & $*$ \\
Ash & $7.9^{\mathrm{ab}}$ & $10.7^{\mathrm{a}}$ & $6.9^{\mathrm{b}}$ & 1.54 & $*$ \\
\hline
\end{tabular}

Means within the same row with different superscripts are significantly different. $* \mathrm{P}<0.05 ; \mathrm{NS}=$ Not significant; SEM = Standard error of mean; NDF = Neutral detergent fibre; ADF = Acid detergent fibre; UPL = Unprocessed poultry litter; SDPL = Sundried poultry litter; EPL = Ensiled poultry litter. LOS = Level of significance. ${ }^{1}$ All values on DM basis except for Dry Matter.

The quantity of feed samples used for the rumen degradation studies were collected from the treated rice straw meant for feeding trials (Ngele, 2008). Hundred kilograms of rice straw was treated in each case. Samples of the rice straw (URS, UTRS, PLTRS1 and PLTRS2) were ground through a $2.5 \mathrm{~mm}$ sieve for the nylon bag study.

\section{Animals and their feeding}

Two white Fulani (Zebu) bulls (of average weight $290 \mathrm{~kg}$ ) at the Abubakar Tafawa Balewa University farm were fitted with permanent ruminal cannulae $40 \mathrm{~mm}$ in diameter. The cannulae was originally intended for small ruminants but it is widely used for Zebu cattle because of its small size, as opposed to Bos taurus that was used for the nylon bag study. The animals were kept in individual pens with free access to water and salt lick. The bulls were offered $4.5 \mathrm{~kg}$ groundnut haulms each and RS was provided on an ad libitum basis. Three grams of the milled samples were weighed into separate nylon bags $(33 \mathrm{~mm} \times 160 \mathrm{~mm}$, pore size $50 \times 27$ microns). The material that could simply be washed from the nylon bags (a), also called washing loss (WL) was estimated by washing two bags per treatment ( 8 samples) after soaking in lukewarm water $\left(39^{\circ} \mathrm{C}\right)$ for one hour. This was done to establish the washing loss before rumen degradation set in. Detailed procedures of the rumen degradation adopted were as described by Ani (1992).

The bags were incubated in the rumen of each bull by being anchored to a 250 $\mathrm{mm}$ plastic tube for periods of $6,12,24$, 48, 72 and 96 hrs. After the bags were removed from the rumen, they were mechanically washed under a continuous flow of running water until clean water 
run through the bags at room temperature $\left(24^{\circ} \mathrm{C}\right)$.

\section{Data collection and analysis}

The dry matter (DM) content of the samples was determined by drying at $60^{\circ} \mathrm{C}$ for $48 \mathrm{hr}$ in an oven. Ash was measured by igniting the samples in a muffle furnace at $500^{\circ} \mathrm{C}$ for 4 hours. Nitrogen $(\mathrm{N} \times 6.25$, or crude protein) content was determined by the automated Kjeldahl method. The neutral detergent fibre (NDF) and acid detergent fibre (ADF) were determined by the method described by Goering and Van Soest (1970). Ether extract was determined using the soxhlet extractor technique.

Data for DM disappearance from the nylon bags was obtained by fitting values to the exponential equation of Orskov and McDonald (1979):

$\mathrm{P}=\mathrm{a}+\mathrm{b}\left(1-\mathrm{e}^{-\mathrm{ct}}\right) \ldots \ldots \ldots \ldots \ldots$...equation 1.

Where, $\mathrm{P}=$ is the disappearance at time $\mathrm{t}$, $\mathrm{a}=$ the rapidly disappearing fraction (zero time intercept), $b=$ proportion of the feed which is slowly degraded with time, $\mathrm{c}=$ the rate constant for the degradation of ' $b$ '.

The data was subjected to analysis of variance (ANOVA) by using the General Linear Model (GLM) with incubation time and treatment methods as fixed factors in SPSS for windows (1996).

The effective DM degradability of the RS based on different ruminal outflow rates was calculated using the equation:

$\mathrm{P}=\mathrm{a}+\mathrm{bc} / \mathrm{c}+\mathrm{k} \ldots \ldots \ldots \ldots \ldots \ldots$......... equation 2 .

Where, $\mathrm{P}$ is the percent disappearance from the nylon bag at time' $t$ '; $a, b$ and $c$ being constants from Equation 1 describing the degradation and, ' $\mathrm{k}$ ' is the fractional outflow rate. The ' $k$ ' value for each RS was calculated (Orskov, 1992).

\section{Results and Discussion}

The composition of the untreated and treated rice straw is shown in Table 2. The crude protein (CP) content of the straw increased with treatment from $4.44 \%$ of the untreated rice straw (URS) to 12.35, 20.46 and $19.72 \%$ for UTRS, PLTRS1 and PLTRS2, respectively. The low CP content of the untreated rice straw observed in this study could be due to alteration in the chemical composition of the straw, affecting the maturity and grain production. The neutral detergent fiber (NDF) of the untreated rice straw is comparatively higher than the acid detergent fibre (ADF). These results are in agreement with those earlier obtained (Taiwo et al., 1992; Manyuchi et al., 1994).

The dry matter (DM) losses from the nylon bag, together with the constants of the fitted exponential equations are shown in Table 3. The degradation characteristics of the straw were similar, while the DM degradation rate (c) ranged from 0.027 to 0.032 fractions per hour. The solubility (a) and potential degradability of DM $(a+b)$ ranged from 5.82 to $10.63 \%$ and 62.7 to $77.8 \%$ respectively. The water soluble fraction was similar for the UTRS and PLTRS1 - 10.63 and $10.16 \%$ respectively. The DM degradability of the treated straw (UTRS, PLTRS1 and PLTRS2) was consistently higher than that of the untreated rice straw. This could be due to the breakdown of the glucosidic linkage in the straw by the ammonia gas released from the hydrolysis of urea fertilizer or uric acid in the poultry litter.

The high potential degradability observed in this study for the treated straw confirms an earlier report with treatments of sorghum stover, maize stover and sugar cane bargasse (Chesson and Orskov, 1984; Orskov et al., 1980; Adu et al., 1993; Bogoro et al., 2006).

The outflow rate $(\mathrm{k})$ at $24 \mathrm{hr}$ and the degradation constant (c) also at $24 \mathrm{hr}$ is shown in Table 3. The ' $\mathrm{k}$ ' and ' $\mathrm{c}$ ' values were $2.66 \% / \mathrm{hr}, 0.032$ and $2.84 \% / \mathrm{hr}$ and 0.028 fractions per hour for UTRS and PLTRS1 respectively. The rate constants (c) for the untreated and treated straw $(0.027,0.032,0.028$ and 0.024 for URS, 
UTRS, PLTRS 1 and PLTRS 2, respectively) recorded in this study fall within values earlier reported for cereal crop residues ( millet, $\mathrm{c}=0.023-0.035$; sorghum, $\mathrm{c}-0.028-0.038$ ) (Orskov and Ryle, 1990; Kibon, 1999). However, the comparative degradability rate (c) and outflow rate at $24 \mathrm{hr}$ of the rice straw showed a close relationship with each other as shown in Fig.1 (Table 3). Similar observation has been made for sorghum stover and other feeds (Bogoro, 1997; Bogoro et al., 1999).

The effect of different outflow rates on effective rumen degradability of the untreated and treated rice straw are shown in Fig 1. The degradability of the URS decreased from 41.07 to $19.90 \%$ as the fractional outflow rate $(\mathrm{k})$ increases from 0.02 to $0.10 / \mathrm{hr}$. There was a similarity in the effective degradability between UTRS and PLTRS1 and, between URS and PLTRS2 as the outflow rate increases from 0.02 to $0.10 / \mathrm{hr}$. The effect of outflow rates on effective rumen degradability of the rice straw showed that an increase in the outflow rate leads to a corresponding decrease in the degradability of rice straw. The rapidly soluble fraction (a) and the rate constant (c) for the degradation of rice straw could have influenced the effective degradability. The dependence of effective degradability $(\mathrm{P})$ on outflow rate (Fig. 1) observed in this study is in agreement with earlier reports that effective rumen degradation depends on the solubility (a), the rate (c) at which the ' $b$ ' fraction is degraded and the outflow rate of small particles (k) (Orskov, 1985).

The low effective degradability of PLTRS $2(19.35 \%)$ at 0.10 outflow rate is comparable to the URS $(19.90 \%)$ at the same outflow rate. This implies that the ammonia hydrolyzed from uric acid in the poultry litter was not enough to cause a major breakdown of the lignocelluloses when compared to the UTRS (29.01\%) and PLTRS1 (25.87\%).

Table 2. Chemical composition of untreated and treated rice straw (\%).

\begin{tabular}{lcccccc}
\hline \multirow{2}{*}{ Composition $^{1}$} & \multicolumn{7}{c}{ RICE STRAW } \\
\cline { 2 - 7 } & URS & UTRS & PLTRS1 & PLTRS2 & SE & LOS \\
\hline Dry matter & 92.8 & 89.98 & 98.91 & 97.19 & 8.95 & NS \\
Crude protein & $4.44^{\mathrm{c}}$ & $12.35^{\mathrm{b}}$ & $20.46^{\mathrm{a}}$ & $19.72^{\mathrm{a}}$ & 0.74 & $*$ \\
Organic matter & 83.9 & 80.5 & 80.5 & 80.0 & 3.90 & $\mathrm{NS}$ \\
NDF & 69.82 & 65.66 & 69.86 & 55.11 & 14.75 & NS \\
ADF & 58.14 & 44.48 & 57.23 & 36.83 & 21.31 & NS \\
Hemicellulose & 11.68 & 21.18 & 12.63 & 18.28 & 9.5 & NS \\
Ether extract & 1.06 & 0.98 & 1.54 & 1.87 & 0.89 & NS \\
Ash & $8.93^{\mathrm{b}}$ & $9.49^{\mathrm{b}}$ & $18.42^{\mathrm{a}}$ & $17.17^{\mathrm{a}}$ & 1.25 & $* *$ \\
\hline
\end{tabular}

abc means within the same row with different superscripts are significantly different $(\mathrm{P}<0.05)$

URS = untreated Rice Straw

UTRS = Urea- treated Rice Straw

PLTRS1 = Poultry Litter Treated Rice Straw (RS: PL; 5:5).

PLTRS2 = Poultry Litter Treated Rice Straw (RS: PL; 6:4)

NDF $=$ Neutral Detergent Fibre

$\mathrm{ADF}=$ Acid Detergent Fibre.

LOS= Level of significance

${ }^{1}$ All values on DM basis except for Dry Matter 
M. B. Ngele et al.

Table 3. Rumen dry matter degradability $(\%)$ of untreated and treated rice straw.

\begin{tabular}{|c|c|c|c|c|c|c|}
\hline & \multicolumn{4}{|c|}{ RICE STRAW ${ }^{1}$} & \multirow{2}{*}{ SE } & \multirow{2}{*}{ LOS } \\
\hline & URS & UTRS & PLTRS1 & PLTRS2 & & \\
\hline \multicolumn{7}{|c|}{ Incubation time (hr) } \\
\hline 6 & $18.68^{\mathrm{b}}$ & $24.18^{\mathrm{a}}$ & $17.05^{\mathrm{c}}$ & $15.69^{\mathrm{c}}$ & 0.17 & $* * *$ \\
\hline 12 & 26.74 & 36.01 & 35.35 & 34.75 & 1.30 & NS \\
\hline 24 & $33.69^{b}$ & $41.35^{\mathrm{a}}$ & $45.61^{\mathrm{a}}$ & $32.49^{\mathrm{b}}$ & 0.78 & $*$ \\
\hline 48 & $49.91^{\mathrm{bc}}$ & $62.93^{\mathrm{a}}$ & $52.99^{\mathrm{ab}}$ & $39.03^{\mathrm{c}}$ & 1.49 & $*$ \\
\hline 72 & $50.93^{\mathrm{b}}$ & $63.34^{\mathrm{a}}$ & $62.65^{\mathrm{a}}$ & $51.7^{\mathrm{b}}$ & 0.57 & $* *$ \\
\hline 96 & $62.7^{\mathrm{c}}$ & $77.2^{\mathrm{a}}$ & $77.8^{\mathrm{a}}$ & $67.13^{\mathrm{b}}$ & 0.75 & $*$ \\
\hline \multicolumn{7}{|c|}{ Constants from fitted equation } \\
\hline A & 7.37 & 10.63 & 10.16 & 5.82 & 2.33 & \\
\hline B & 54.7 & 66.5 & 67.2 & 61.5 & 7.75 & \\
\hline $\mathrm{C}$ & 0.027 & 0.032 & 0.028 & 0.024 & 0.004 & \\
\hline 24 hr "k" & 3.3 & 2.7 & 2.8 & 3.0 & & \\
\hline
\end{tabular}

URS = untreated Rice Straw

UTRS $=$ Urea- treated Rice Straw

PLTRS1 $=$ Poultry Litter Treated Rice Straw (RS: PL; 5:5).

PLTRS2 $=$ Poultry Litter Treated Rice Straw (RS: PL; 6:4)

$\mathrm{SE}=$ Standard error

LOS= Level of significance

$\mathrm{a}=$ Rapidly disappearing fraction (zero incubation time)

$\mathrm{b}=$ Proportion of straw degraded with time

$\mathrm{c}=$ Rate constant for the degradation of ' $\mathrm{b}$ '.

$\mathrm{k}=$ outflow rate at $24 \mathrm{hr}(\% / \mathrm{hr})$

${ }^{1}$ All values on DM basis except for Dry Matter

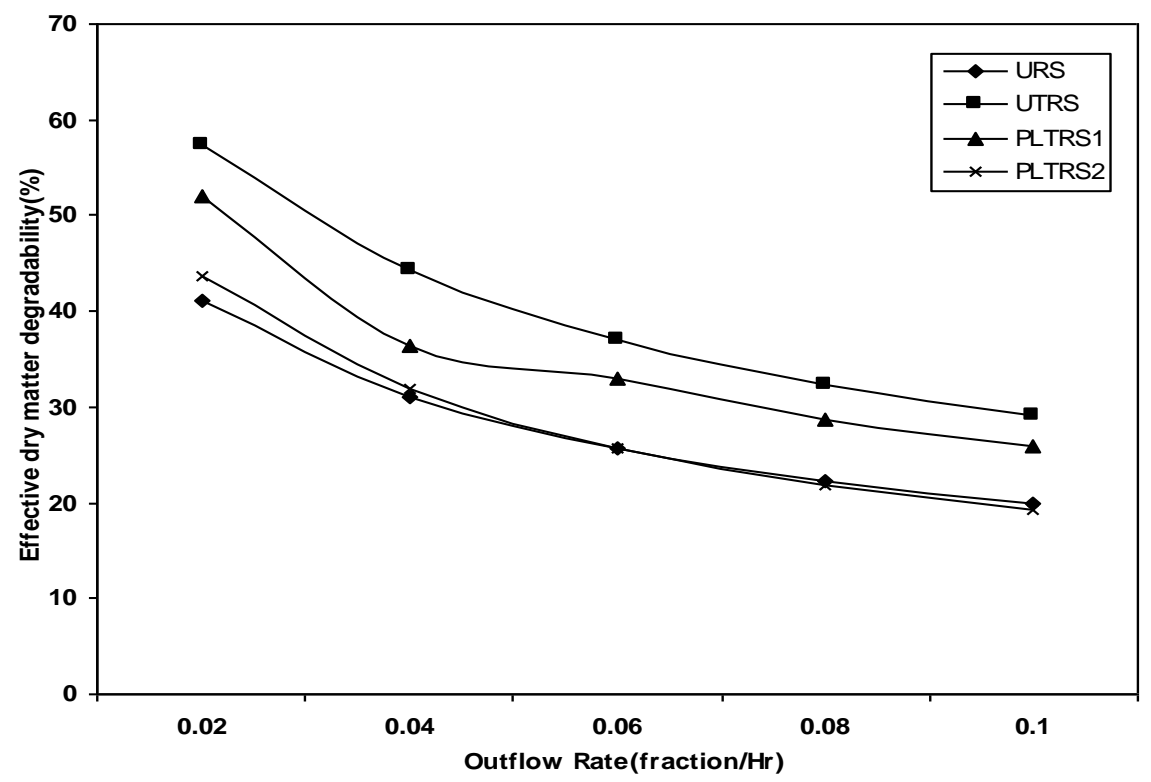

Figure 1. Effect of different outflow rates on effective degradability of untreated and treated rice straw.

URS = untreated Rice Straw

UTRS = Urea- treated Rice Straw

PLTRS 1 = Poultry Litter Treated Rice Straw (RS: PL; 5:5)

PLTRS 2 = Poultry Litter Treated Rice Straw (RS: PL; 6:4) 


\section{Conclusion}

The present study shows that the crude protein content in crop residues can be increased by ammoniation. The study also reveals that ammoniation changes straw in such a way that its dry matter disappearance from the nylon bags either by dissolution, digestion or loss of fine particles is increased in the rumen. The use of poultry litter in treating crop residues will serve as an effective alternative to urea fertilizer which is scarce, expensive and unaffordable by most rural livestock farmers. In addition, this will go a long way in reducing the problem of animal waste disposal in urban areas. However, the ratio of rice straw to poultry litter is quite important in effective treatment of crop residues. This trial showed that an equal proportion of rice straw to poultry litter is most effective in the treatment process. The use of urban animal waste (poultry litter) should be handled with care so as to avoid public health risk.

\section{Acknowledgement}

The authors are grateful to the Abubakar Tafawa Balewa University (ATBU) for their support in this study.

\section{References}

Adegbola, T. A., R. C. Ogbonna and E. E. Nwackukwu. 1988. Nutrient intake, digestibility and rumen studies of goats fed varying levels of cassava peels and brewers dried grain. Nigerian Journal of Animal Production. 15:161-166.

Adu, I. F., E. A. Lufadeju, C. A. M. Lakpini and W. S. Alhassan.1993. Effect of treatment on the utilization of maize stover by Yankasa sheep. The Small Ruminant Research Network. Newsletter No. 25.
Ani, M. T. 1992. Rumen degradability of plant and animal proteins using locally cannulated bulls. B. Agric. Tech. Dissertation (Unpublished). A.T.B.U, Bauchi, Nigeria.

Bayer, W. 1986. Agro pastoral herding practices and grazing behaviour of cattle in the sub humid zone of Nigeria. ILCA Bulletin No. 24. ILCA, Addis Ababa, Ethiopia.

Bogoro, S. E. 1997. Effect of proteinenergy supplementation on rumen kinetics, metabolic profile and growth performance of rams fed high fibre diets. Ph. D Thesis. A.T.B.U., Bauchi, Nigeria.

Bogoro, S., T. A. Adegbola, A. M. Adamu, W. S. Alhassan and N. N. Umunna. 1999. In-vitro rumen gas production versus in-situ (in-vitro) rumen kinetics of sorghum stover. Tropical Journal of Animal Science. 1(2):109-117.

Bogoro, S., D. J. U. Kalla and B. Fomukong. 2006. Chemical composition and in-situ rumen degradability of blood meal and ureatreated crop residue. Nigerian Journal of Experimental and Applied Biology. 7(1):27-35.

Chesson, A. and E. R. Orskov. 1984. Microbial degradation in the digestive tract. In: Straw and other fibrous byproducts as feed. F. Sundstol and E. Owen (eds.). Amsterdam, Elsevier Science.

Goering, H. K. and P. J. Van Soest. 1970. Forage fibre analysis. USDA-ARS Agricultural Handbook, No. 378, U.S. Government Printing Office, Washington, D.C.

Kempton, T.J. 1980. The use of nylon bags to characterize the potential 
degradability of feeds for ruminants. Tropical Animal Production. 5:107116.

Kibon, A. 1992. Rate of rumen degradation of different varieties of millet and sorghum stover. In:

Proceedings of the $26^{\text {th }}$ annual NSAP conference held 21-25 March. Ilorin, Kwara State, Nigeria. pp. 41-44.

Manyuchi, B., S. Mikayin and T. Smith. 1994. Effect of treatment or supplementing maize stover with urea on its utilization as feed for sheep and cattle. Animal Feed Science and Technology. 49:11-23.

Mehrez, A. Z. and E. R. Orskov. 1977. A study of the artificial fibre bag technique for determining the digestibility of feed in the rumen. Journal of Agricultural Science (Cambridge). 86:645-650.

Ngele, M. B., T. A. Adegbola, S. E. S. Bogoro, A. Chiroma and G. T. Williams. 2003. Effect of processing methods on the Nutrient composition and pathogenic microbial flora of poultry litter. Agriculture, Business and Technology Journal. 1(2):37-140.

Nuru, S. 1993. Keynote Address, Forage production and utilization in Nigeria. In: Proceedings of the $2^{\text {nd }}$ Livestock Development Project Workshop, Zaria, Nigeria. 11-14 February. 1991. A. M. Adamu, R. I. Mani, O. A. Osiniwo, K. B. Adeoyi and E. O. Ajileye (Eds.). pp. 4 -9.

Oddoye, E. O., K. Amaning-Kwarteng, E. K. Awotwi and J. E. Fleischer. 2005. In-sacco degradability of grass and hay and rumen characteristics in sheep fed urea ammoniated rice straw or untreated supplemented rice straw. Bulletin of Animal Health and Production for Africa. 53(2):113-123.

Orskov, E. R. 1985. Supplementation of low quality roughage diets for optimal microbial and host animal nutrition. In: Use of agricultural by-products in developing countries. K. El-Shazly (Ed.) University of Alexandria.

Orskov, E. R., F. D. Deb Hovell and F. Mould. 1980. The use of the nylon bag technique for the evaluation of feedstuffs. Tropical Animal Production. 5:195-213.

Orskov, E. R. and I. McDonald. 1979. The estimation of protein degradability in the rumen from incubation measurements weighted according to rate of passage. Journal of Agricultural Science (Cambridge). 92:499-503.

Orskov, E. R. and M. Ryle. 1990. Energy nutrition in ruminants. Elsevier Science Publishers Ltd.

SPSS. 1996. Statistical Package for Social Sciences, SPSS/STAT, Version 7.5 for Windows.

Sundstol, E. and E. Owen. 1984. Straw and other fibrous by-products as feed. Elsevier Amsterdam.

Taiwo, A. A., E. A. Adebowale, J. F. D. Greenhalgh and A. O. Akinsoyino. 1992. Effect of urea treatment on chemical composition and degradation characteristics of some crop residues. Nigerian Journal of Animal Production. 19:25-35. 